\title{
EXCURSION TO BUXTON AND NORTH DERBYSHIRE.
}

Whitsuntide, MAY 2 IST to May $25 \mathrm{TH}$, I 904.

Directors: H. Arnold Bemrose, assisted by Prof. Boyd

Dawkins, H. H. Hubbersty, Esq., and

H. LAPWORTH, EsQ.

Excursion Secretary: H. KIDNER.

(Report ly The Directors.)

On the evening of Miay zoth the majority of the members attending the excursion had assembled at the comfortable headquarters, the "Crescent Hotel," Buxton.

\section{Visit to Derwent Valiey Water Works. MAY 2 IST, I904.}

By the kind permission of the Derwent Valley Water Board members of the Association were enabled to pay a visit to the Derwent Valley Water Works, which are now in progress for the supply of water to the towns of Leicester, Derby, Nottingham, and Sheffield.

The members arrived at Bamford Station at I0.15 a.m., whence they were conducted to the Board's railway connecting the Midland Railway at Bamford with the Water Works. At the Board's offices - where this line commences-a special train had been provided for conveying the members to the Water Works.

During the journey the thinning-out of the "Lower Kinder Scout Grit" on Bamford Edge was noticed, also the Sheffield Tunnel Works, the local landslips, and various other items of interest.

The members proceeded first to the "Howden" Dam site, where excavations are being carried out for the foundations of the "Howden" Dam. This is the higher of the two dams which are to be constructed in the Derwent Valley. The trench has been taken down to a depth of about $80 \mathrm{ft}$. in the Yoredale Shales Formation of the Carboniferous System, exposing a huge fold or wrinkle which extends from the ground surface to the bottom of the trench. The following sketch-reproduced from a photograph--shows the manner in which the beds have been folded, faulted, and packed.

Practically the whole base of the central portion of the dam will rest on the foundation shown in the sketch, but at the north side of the excavation a narrow trench has been sunk below this level extending to such a depth that all water percolating through 
the disturbed ground will be intercepted after this narrow trench has been filled in with concrete.

Three theories have been advanced as to the formation of this wrinkle, which forms one of many in the Derwent Valley: (I) That they assumed their present form during the "Pennine" movement; (2) That they originated during the "Pennine" movement, and have been augmented by subsequent movement;

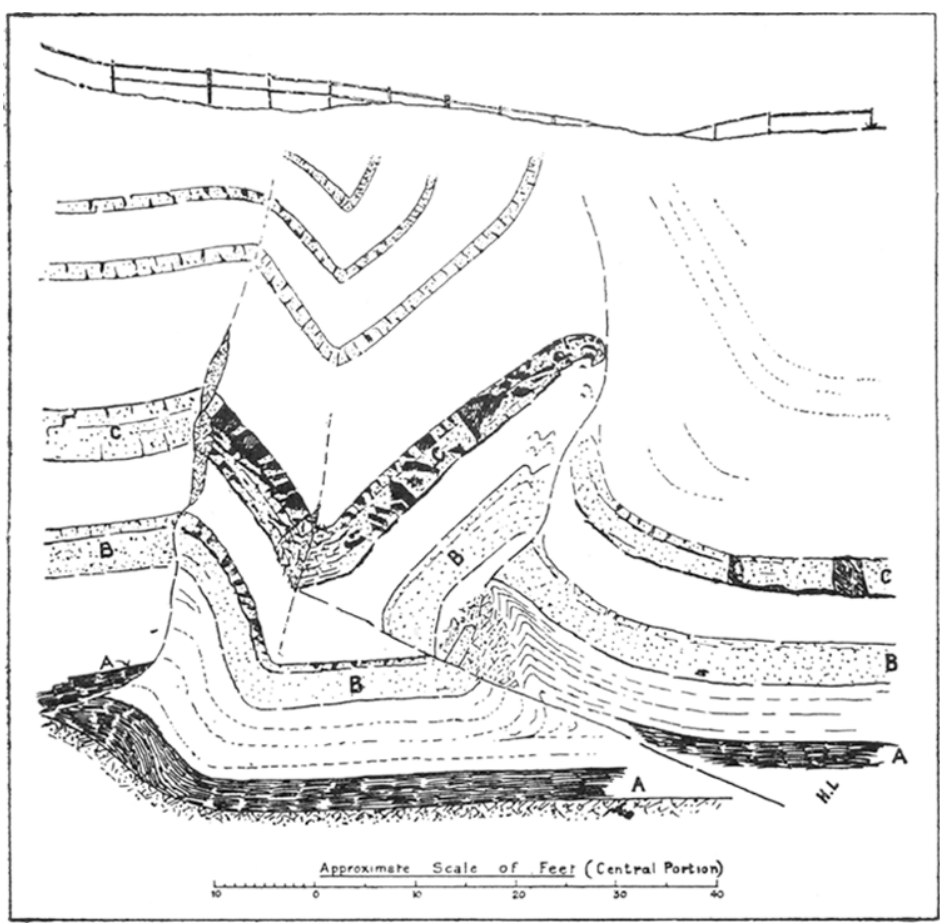

Fig. 22.-Contorted Beds in The Derwent Valley.

a. - Is a distinctive bed of carbonaceous black shales.

b. and c -Are two separate sandstone beds, each about $4 \mathrm{ft}$. thick.

(3) That they are of comparatively recent date. Prof. Boyd Dawkins pointed out that the evidence in these trenches cut across the bottom of the valley of the Derwent indicated that the faulting and crumpling of the shales and thin sandstones were due not to the ordinary faults and folds, but to a "creep "similar to that in deep mines, caused by the relaxation of pressure brought about by the removal of rock during the excavation of the valley by the stream, while the pressure remained as before in the hills on each side. He found that this was the rule rather 
than the exception in all valleys cut deeply into Yoredales and Millstone Grits. In all cases the creep extends to no great depth, and the rocks are undisturbed below.

These wrinkles are characteristic of the Derwent Valley, and appear to be most prominent in the bottom of the valley. Their general direction is from north to south, or from north-north-west to south-south-east. It might be mentioned here incidentally that on the western side of the Kinder scout anticline, where a more rapid change of dip has taken place from the level strata of Kinder Scout itself towards the steeply inclined beds to the westward, a similar set of north to south wrinkles occurs, but they show greater disturbance, and more often pass into faults of considerable displacement. A few cross folds from east to west can be observed in the Derwent Valley, but they do not reach the proportions of those running from north to south. It is possible that these are the result of the small "Pendle" movement which Prof. Hull believes to have taken place slightly before the great "Pennine" movement.

Leaving the Howden Dam the party proceeded to the "Derwent" (or lower) Dam. Here the wrinkling and faulting has been more extensive, but the individual wrinkles are not of such magnitude as the "Howden" fold, and considerable cross faulting has taken place. Unlike the shales of the Howden trench the "Yoredales" at Derwent Dam are highly fossiliferous in certain beds. Mr. Stobbs, F.G.S., has identified the following species :

\section{Pterinopecten papyraceus. Orthoceras pygmeum. Posidoniella lavis. \\ Pleuronautilus, sp. Glyphioceras diadema.}

Glyphioceras reticulatum. Dimorphoceras gilbertsoni. Calamites. Rhizodus? Lingula?

This fauna appears to conform to that of the typical "Pendleside " strata of Messrs. Hind and Howe.

An examination was made of a collection of fossils which were obtained from the trench and exhibited by the Resident Engineer, Mr. M. G. Weekes.

At this stage, Mr. Sandeman and Mr. Winser, the Engineer and Deputy Engineer, pointed out and explained the cableways and other items of engineering interest which were to be seen.

Leaving the Derwent Dam the party proceeded to Ashopton, where lunch was obtained, after which members proceeded to Bamford, where they left the train for brakes. A drive followed of about four miles to the Bole Hill Quarries. Here stone is being obtained for the building of the dams. The party dismounted at "The Surprise," which lies immediately above the Quarries and commands an extensive view of the surrounding 
country. Here, Professor Boyd Dawkins gave a most interesting address on the geology of the district, explaining how the great north and south anticlinal arch, composed of Carboniferous Limestone, Yoredale and Millstone Grit, which forms the massif of the Pennine Chain, had been carved out by the agencies of denudation. Mr. Lapworth followed, giving a resumé of Dr. Hind's theories as to the derivation of the grits.

The Quarries are in the "Rivelin Grit" Bed of the "Millstone Grit" Series. "The rock contains a large proportion of felspar and some mica; it appears to have been derived from a granitic area. Petrological experts who were present were of the opinion that the material is not of very distant origin. After a collection of hand specimens and an examination of the working arrangements of the Quarries had been made, the party proceeded to the "Maynard Arms," where tea was served, and left Grindleford at 5.25 p.m. for Buxton.

MAY 22ND, I9O4.

Some of the members visited the IVye valley near Miller's Dale, and admired the magnificent Tor in Chee Dale, and a short distance above it up the river the narrow gorge in the lower parts of the valley. They returned to Wormbill springs, which issue from above the lava, proceeded by Wormhill to Great Rocks Dale, and examined and discussed the evidence for one or two faults which have let down a small portion of the Toadstone, so that it abuts against the limestone. They noticed a decided change of feature, from a narrow rocky dale shut in by limestone cliffs, to a grass-covered, gently-sloping valley in the softer lava. They then walked over an intrusive sill to Waterswallows, where they found some erratics of igneous rocks foreign to the county, and visited numerous swallow-holes, down some of which they saw water disappear.

\author{
MAY 23RD, I904. \\ Dirctors: Prof. BOYd Dawkins, H. A. HUBbersty, \\ H. ARNOLD BeMrRose. \\ Report by H. ARNOLd Bemrose.
}

The party walked to Sherbrook and examined section of vesicular lava on the roadside, thence by fields to Staden Low to see lava faulted against limestone; evidences for the fault were pointed out on the west and east sides of the Low. From the Low fine views of the surrounding country were seen. On the west side Mr. Hubbersty pointed out the interesting features in the landscape, and Mr. Bemrose gave a brief description of the geology and showed that the view embraced the north-west portion of the mountain limestone region in the foreground and the Yoredales and grits in the distance, to the north were seen the Peak and Mam Tor near Castleton, and to the east the main 
mass of mountain limestone country. The members proceeded by Foxlow Farm to Harper Hill Quarry, where Prof. Boyd Dawkins met them.

At Harper Hill the members were shown the Iimestone Quarries of the Buxton I.ime Firms Company, Limited. The beds of limestone are thrown up and separated by vertical faults as shown by the plan and section (Fig. 23). From which
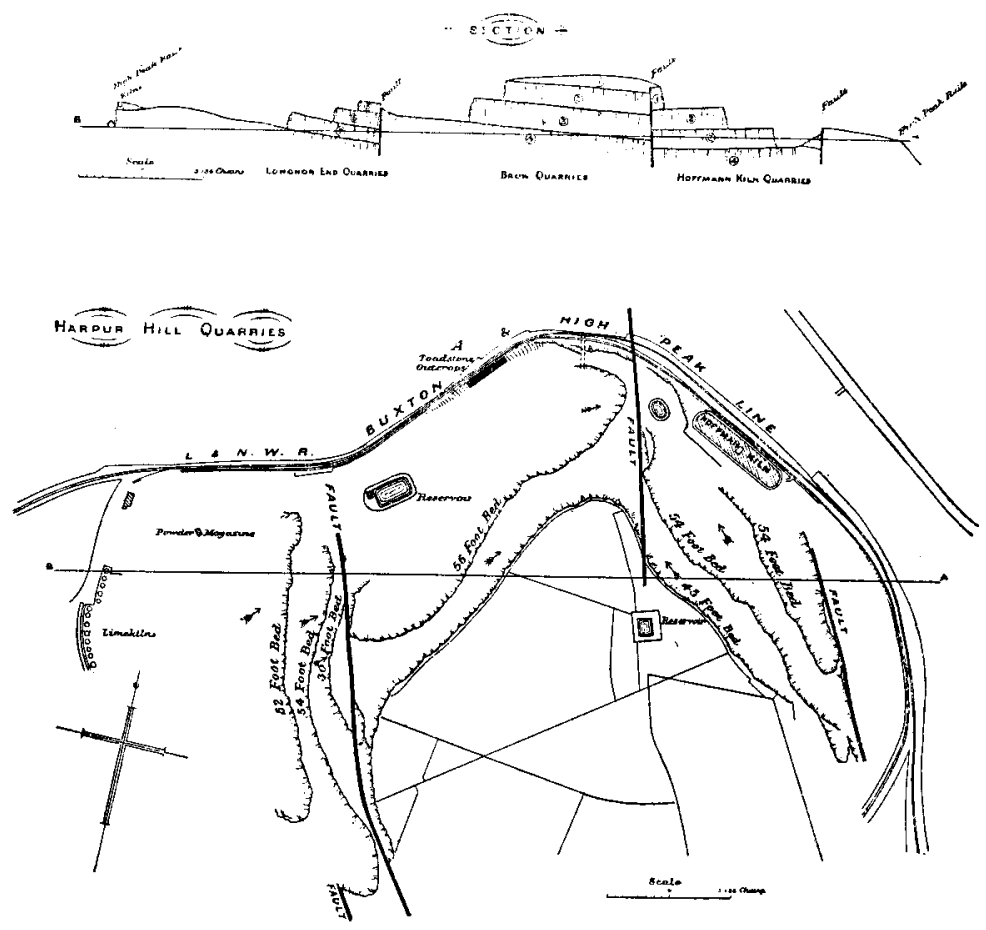

FIG, 23.-PLAN AND SECTION, HARPER HILL QUARRIES.

it will be seen that the beds are not only altered in "dip," but are also very much displaced.

The quality, or texture, and the colour of the stone in the several beds were shown to vary considerably, and it was difficult to trace, definitely, whether the beds Nos. 2 and 3, in the Hoffman Quarry, or northern portion of the section, are the same as Nos. 2 and 3 in the Brow Quarries, or central portion, although there is a great similarity in the stone. 
The beds in the Longnor End Quarries, on the south, Nos. 5, 6 and 7 , do not correspond with any of the preceding; but resemble those subsequently seen at the Grin Quarries. They are probably below the Toadstone, as a similar bed to No. 5 is worked by the Lime Firms Company at Millers Dale, under the Toadstone.

A bed of Toadstone was pointed out under No. 4 bed in the centre portion, or Brow Quarries, at the point marked A on the plan, adjoining the High Peak Railway; but it has not been found in any other portion of this Quarry or at Grin Works.

The beds of clay-part blue, part yellow-which separate Nos. 2 and 3 limestone beds, with the fossils underneath, were examined. The analysis of each clay is as follows :

\begin{tabular}{|c|c|c|c|c|c|c|}
\hline & & & & ue Clay. & & llow Clay. \\
\hline Silica & ... & $\cdots$ & & 38.75 & $\cdots$ & 36.5 \\
\hline Alumina $\ldots$ & ... & $\cdots$ & $\cdots$ & 35.90 & $\ldots$ & 32.8 \\
\hline Iron Oxide $\quad \because$ & $\ldots$ & $\ldots$ & $\ldots$ & .25 & $\ldots$ & 2.9 \\
\hline Lime and Magnesi & & $\ldots$ & $\ldots$ & 3.75 & $\ldots$ & 4.2 \\
\hline Loss on Calcination & & $\ldots$ & $\ldots$ & 20.23 & $\ldots$ & 22.7 \\
\hline
\end{tabular}

The fault Breccia was particularly interesting, many portions of the rock fragments being dolomitised, and covered w.th a considerable thickness of crystals. (The clay with which some faults are filled being apparently of a similar character to that in which the Pliocene remains were found in the Dove Holes cavern, near Buxton, the working at a lower level might possibly produce corresponding evidence.) Nodules of lead ore, of copper ore, and of "cawk," or barytes, have been at times found in it; but unfortunately no regular and careful examination has been made during the quarrying process.

After leaving the Quarry the party proceeded to the site of the New Buxton Waterworks, near Ladmanlow, where Prof. Boyd Dawkins pointed out the fault between the Mountain Limestone and Yoredale Shales, and explained the method of construction of the proposed reservoir. Several swallows in the limestone, down which water from the shales was disappearing, were examined. In some of these were Yoredale and Millstone Grit pebbles. Grin Low Quarry was next visited. Prof. Boyd Dawkins pointed out several hollows or caverns in the limestone filled with more or less weathered pebbles of Millstone Grit, and gave a most delightful account of his find at Doveholes of Pliocene bones, and suggested that such a hollow in which be stood was just the kind of place for geologists to search for Pliocene mammalia.

Pooles Cavern was visited, and the party proceeded to the Buxton Museum, where the Professor described the portion of the Doveholes Pliocene bones, which were in a glass case. 


\section{MAY $24 \mathrm{TH}, \mathrm{I} 904$. \\ Director: H. ARnold Bemrose.}

The party proceeded to Ambergate by train and walked to Crich Village. By the kindness of the Butterley Company they visited Hill's Quarry and the adjoining old quarry, in which very fine specimens of Boulder Clay were seen. The clay is a tough reddish or bluish deposit with streaks or patches of sand, sandy gravel, or sandy clay. It is thickly studded with boulders, many of which were seen to be finely polished or grooved. The boulders examined included limestone, gritstone, sandstone, toadstone, Bunter pebbles, and various foreign greenstones and granites. The Director pointed out a boulder of curious rock of a pinkish felspathic base studded with green specks. It was thought to be spherulitic, but none of the party could name it. A patch of "calcrete," consisting of boulders and pebbles of sandstone and Bunter pebbles cemented together, and suggestive of glacial action, was seen. Portions of the striated floor of limestone from which the clay had been lately removed were examined.

Attention was called to a "wayboard" or bed of clay in the limestone. Such beds are common in the limestone. The surface of limestone under these clays and also under the lava streams is often worn into a pothole-like structure. A discussion arose as to whether the weathering took place subsequent to the deposition of the clay or whether the weathered surface denoted some erosion of this limestone before the clay was deposited. In support of the latter view it was pointed out by one of the members that whilst the surface of the limestone below the clay contained these irregularly shaped hollows the surface of the limestone above the clay was an ordinary bedding plane free from such hollows.

Part of an old cavern was seen in section. The hollow was filled with clay and decomposed limestone, and portions of two stalactites were found in it.

Before leaving the Quarry the President thanked Mr. Bemrose and $\mathrm{Mr}$. Coke for arranging and carrying out such an enjoyable excursion in Derbyshire.

The party walked back to Ambergate through Fritchley. Some members returned to London and the remainder to Buxton.

MAY $25 \mathrm{TH}, 1904$.

\section{Direcior: H. ARNold BemRose.}

The party left Buxton by train for Mousal Dale Station, and visited the spar mine near the station. The calc-spar containing traces of galena and barytes fills a rake vein about 8 feet in width. The members walked along the level for about 600 yards, and saw the underground workings. Mr. Money Kent

Proc. Geol. Assoc., Vol. XVIII, Part 8, Ig04.] 
collected specimens of the curious fungi growing on the timber in the "level." Many members led by Mr. Froggatt penetrated the recesses of the mine, and by means of ladders and stempals and sloping paths, visited part of the old lead mine, and the various levels at which the spar is worked, and finally emerged to daylight at a height of 500 feet above the place of entry. A hearty vote of thanks to $\mathrm{Mr}$. Froggatt for his kindness was proposed by Mr. Whitaker. A descent was made into the dale, and on the way up to the Headstones a small limestone quarry was visited. The rocks consisted of thin beds of black limestone with partings of blach chert. At the Headstones the Director pointed out the magnificent views of the Wye valley and the surrounding country, and led the visitors down into the rabbit warren. For the first time during the excursion the rain descended in a fine drizzle.

On the way, the upper lava in the bank of the river was pointed out, and two small quarries in tufa were examined. The two lava flows, separated by about $5^{\circ}$ feet of limestone, were seen on the slopes of Fin Cop. At New Bridge the upper lava stream below the thin cherty limestones was seen. The Director drew attention to the vesicular and slaggy lava, and to the hard spheroidal coarse-grained ophitic dolerite below it, and said that he considered it was a similar case to that in Tideswell Dale, where a sill, or intrusive rock, had pushed its way up and proceeded along a plane of weakness below and up to the lower part of the lava flow. From here the party drove through Ashford to Bakewell, and visited the Holme Bank chert quarries. Large blocks of siliceous rock are obtained and sent to the potteries for grinding purposes. Mr. Long, the manager, met the members and conducted them through some of the underground workings. The method of mining the rocks by undercutting was explained. The siliceous bed is about 4 feet thick, and is unlike the chert often found in the limestones. Some beds are traversed by threads or veins of silica. Some geodes were found with crystalline quartz, and here and there were chalcedony-like masses.

The Director on being asked about the microscopic structure of the siliceous rock said that the pieces he had examined consisted of a microcrystalline quartz mosaic often passing into a cryptocrystalline structure, which contains small patches of the former; and that the threads of silica which traverse the rock are composed of a mosaic of clear quartz grains which have no crystalline outline, and are not elongated like those in the quartz rock at Bousall and Castleton. A vote of thanks to $\mathrm{Mr}$. Long terminated the geological part of the excursion. After tea at Bakewell the members returned to London, Derby, and Birmingham.

NOTE.-The great interest in underground fungi is that they 
are generally in an abnormal state, and therefore most difficult to determine. Three kinds were found in the Spar mine :

I. Ozonium auriconium.-This is the brown old-man's-beardlike material in the mycelium of a fungus undetermined because it has never been known to fructify. The beautiful white silky material hanging down somewhat similarly is probably a young form of the same fungus.

2. Coprinus atramentarius.

3. Polyporus.-Too abnormal to be named specifically.

The above have been verified by Mr. V. H. Buckman, of the British Museum (Cryptogams).

\section{REFERENCES.}

Geological Survey Maps, $x$-inch: Sheet 8I, S.E., Buxton and Bakewell ; Sheet $8 \mathrm{r}$, S.W., Poole's Hole ; Sheet $7 \mathrm{I}$, N.W., Crich.

No. 1. I 887 . "Memoir of the Geological Survey, N. Derbyshire."

No. 2. 1894. BEmRose, H. H. ARNOLD.- "On the Microscopical Structure of the Carboniferous Dolerites and Tuffs of Derbyshire." Quart. Fourn. Geol. Soc., vol. 1, pp. 603-644.

No. 3. I 899. BEMrose, H. H. ARNOL.D. "A Sketch of the Geology of the Lower Carboniferous Rocks of Derbyshire." Proc. Geol. Association, vol. xvi, p. 165 .

No. 4. Igoo. Dale, ElizabeTh.- "The Scenery and Geology of the Peak of Derbyshire." Sampson Low \& Co.

No. 5. I 900 DeEleY, R. M.--"Fine Section of a Boulder Clay at Crich." Geol. Mag., Oct., I900, pp. 476, 477 .

\section{ORDINARY MEETING.}

\section{FRIDAY MARCH 4TH, I904.}

A. Smith Woodward, LL.D., F.R.S., President, in the Chair.

The following were elected members of the Association : T. R. Croger, Ruthven Finlayson, William D. Shuard.

The President referred in sympathetic terms to the loss sustained by the Association by the death of its former President, Lieut.-General C. A. McMahon.

Dr. C. Gilbert Cullis then exhibited, by means of the lantern, about fifty beautiful photographs, comprising the first two series issued to subscribers by the British Association Geological Photographs Committee. After a brief explanation of the manner in which the photographs are issued, Dr. Cullis proceeded to point out in a lucid manner the principal features exhibited by each of the slides. 